\title{
Efektivitas ekstrak etanol daun ungu (Gratophyllum pictum (L.)) untuk menurunkan kadar TNF- $\alpha$ dan NO
}

\author{
Nur Patria Tjahjani ${ }^{1}$, Tri Nur Kristina ${ }^{2}$, Endang Sri Lestari ${ }^{2}$ \\ ${ }^{1}$ Akademi Farmasi 17 Agustus 1945 Semarang \\ Jl. Jendral Sudirman 350 Semarang 50149 \\ ${ }^{2}$ Program Studi Magister Ilmu Biomedik Fakultas Kedokteran Universitas Diponegoro Semarang \\ Jl. Dr. Soetomo 18 Semarang 50131
}

Submitted: 22-03-2016

Reviewed: 05-04-2016

Accepted: 03-11-2016

\begin{abstract}
ABSTRAK
Ekstrak daun Ungu (Gratophyllum pictum L.) mengandung senyawa fitokimia antara lain alkaloid, tannin dan flavonoid yang mempunyai aktivitas antibakteri terhadap Staphylococcus aureus (S. aureus). Penelitian ini bertujuan untuk membuktikan efektivitas ekstrak etanol daun ungu dalam menurunkan kadar TNF- $\alpha$ dan NO pada mencit Swiss yang diinfeksi S. aureus. Penelitian ini menggunakan mencit Swiss sebanyak 30 ekor yang dibagi menjadi 5 kelompok perlakuan, yaitu $\mathrm{K}(-)$ mencit sehat; $\mathrm{K}(+)$ mencit yang diinfeksi $S$. aureus; P1, P2, P3 masingmasing diinfeksi S.aureus dan diberi ekstrak etanol daun ungu sebanyak 75, 150, dan $300 \mathrm{mg} / \mathrm{kgBB} / \mathrm{hari}$ selama 7 hari. Rerata kadar TNF- $\alpha$ kelompok K(-), K(+), P1, P2, P3 secara berurutan 300,29; 550,29; 390,34; 517,67; dan $327,55 \mathrm{pg} / \mathrm{mL}$. Uji One Way ANOVA menunjukkan ada perbedaan bermakna pada kelima kelompok perlakuan $(p=0,001)$, uji Post Hoc LSD kelompok P1 dan P3 berbeda bermakna dengan kelompok K $(+)$ dengan $p=0,013$ dan $p=0,001$. Rerata kadar NO kelompok $\mathrm{K}(-), \mathrm{K}(+), \mathrm{P} 1, \mathrm{P} 2$, P3 secara berurutan adalah 1,$32 ; 3,56 ; 2,50 ; 2,64$; dan $1,56 \mu \mathrm{M} / \mathrm{mL}$. Hasil uji Kruskal Wallis menunjukkan kadar NO tidak berbeda bermakna, meskipun kadar NO pada dosis $300 \mathrm{mg} / \mathrm{kgBB} / \mathrm{hari}$ mendekati kadar NO pada kelompok K(-). Hasil uji korelasi Spearman menunjukkan adanya korelasi antara TNF $\alpha$ dan NO dengan hasil bervariasi pada setiap kelompok perlakuan. Ekstrak etanol daun ungu $300 \mathrm{mg} / \mathrm{kgBB} / \mathrm{hari}$ selama 7 hari merupakan dosis efektif untuk menurunkan kadar TNF- $\alpha$ dan NO pada mencit Swiss yang diinfeksi S. aureus.
\end{abstract}

Kata kunci: Ekstrak etanol daun ungu, Staphylococcus aureus, TNF- $\alpha$, NO

\section{ABSTRACT}

Ethanol extract of Gratophyllum pictum L (G. pictum L). leaves contain phytochemical compounds such as alkaloids, tannins and flavonoids, which have antibacterial activity against Staphylococcus aureus. This study aims to prove the effectiveness of ethanol extract of G. pictum L. to reduce the level of TNF- $\alpha$ and NO in Swiss mice infected with $S$. aureus. The study treated 30 Swiss mice divided into 5 groups, consist of: K (-) normal mice ; K (+) mice were infected with $S$. aureus ; P1, P2, P3 were infected with $S$. aureus and given the ethanol extract of $G$. pictum leaves, 75,150, and $300 \mathrm{mg} / \mathrm{kgBW} /$ day for 7 days . Mean levels of TNF- $\alpha$ of group K(-), K (+), P1, P2, P3 were $300.29 ; 550.29 ; 390.34 ; 517.67 ; 327.55 \mathrm{pg} / \mathrm{mL}$ respectively. One Way ANOVA test showed that there were significant differences between all treatment groups $(\mathrm{p}=0.001)$, LSD Post Hoc test revealed P1 and P3 groups different significantly with $\mathrm{K}(+)$ with $\mathrm{p}=0.013$ and $\mathrm{p}=0.001$. Mean levels of $\mathrm{NO}$ of group $\mathrm{K}(-), \mathrm{K}(+), \mathrm{P} 1, \mathrm{P} 2, \mathrm{P} 3$ were $1.32 ; 3.56 ; 2.50 ; 2.64$; and $1.56 \mu \mathrm{M} / \mathrm{mL}$ respectively. Kruskal WallisTest showed that the levels of NO not significantly different, although NO levels at $300 \mathrm{mg} / \mathrm{kgBW} /$ day similar with to the levels of NO group $\mathrm{K}(-)$. Spearman correlation test showed that there were correlations between TNF- $\alpha$ and NO with the variation results on each treatment groups. Ethanol extract of G. pictum leaves at $300 \mathrm{mg} / \mathrm{kgBW} /$ day for 7 days is regarded as the effective dose to reduce TNF- $\alpha$ and NO levels in Swiss mice infected by S. aureus.

Keywords: Ethanol extract of Gratophylum pictum leaves, Staphylococcus aureus, TNF- $\alpha$, NO

Penulis korespondesi:

Nur Patria Tjahjani

Akademi Farmasi 17 Agustus 1945 Semarang

Jl. Jendral Sudirman 350 Semarang 50149

Email: nurpatriacahyani@gmail.com 


\section{PENDAHULUAN}

Penyakit infeksi masih merupakan salah satu masalah kesehatan masyarakat yang penting, khususnya di negara berkembang termasuk Indonesia. Salah satu penyebab penyakit infeksi adalah S.aureus, bakteri Gram positif yang sering dijumpai di alam dan penyebarannya melalui kontak dari manusia ke manusia, peralatan yang ada di rumah sakit maupun melalui udara (Lestari et al., 2012). Penularan dapat terjadi karena adanya kontak langsung dengan penderita yang terinfeksi $S$. aureus (Okeke et al., 2005).

Obat andalan yang digunakan untuk menangani masalah infeksi adalah antibiotik. Penggunaan antibiotik yang relatif tinggi dan tidak didasarkan pada indikasi menimbulkan permasalahan bagi kesehatan terutama resistensi. Methicillin Resistant Staphylococcus aureus (MRSA) merupakan kuman yang resisten terhadap semua antibiotik golongan beta lactam (Lestari et al., 2012). Penyakit infeksi yang berkaitan dengan resistensi antibiotik pada umumnya disebabkan oleh adanya gangguan pada sistem imunitas pejamu (Nickerson et al., 2009).

Produk bakteri karena infeksi $S$. aureus berupa fragmen dinding sel peptidoglikan dan asam lipoteikoat yang dapat menginduksi pelepasan Tumor Necrosis Factor (TNF- $\alpha$ ) dan IL-1 $\beta$ (Wang et al., 2000), suatu pirogen endogen yang merangsang inflamasi akut pada kadar rendah (Baratawidjaja dan Rengganis, 2009). Pelepasan TNF- $\alpha$ akan memicu aktivitas makrofag. Stimulasi makrofag oleh peptidoglikan dan TNF- $\alpha$ akan memicu transkripsi gen yang meningkatkan kadar Inducible Nitric Oxyde Synthase (iNOS). Peningkatan iNOS akan diikuti dengan pembentukan Nitrit Oksida (NO) (Giuseppe et al., 2006, Sharma et al., 2007, Abbas et al., 2012). Peningkatan kadar TNF- $\alpha$ yang berlebihan akan meningkatkan sekresi NO yang berlebihan juga, sehingga akan terjadi sepsis shock dan kerusakan pada berbagai organ (Gillian et al, 2001). Beberapa studi eksperimental menunjukkan bahwa ekstrak etanol daun ungu mempunyai kemampuan analgesik dan anti inflamasi pada hewan coba (Ozaki et al,.1989, Sumastuti 2000), karena adanya kandungan alkaloid dalam daunnya (Erlin dan Marline, 2011). Ekstrak daun ungu mempunyai aktivitas anti inflamasi yang lebih besar dari indometasin (Sumarny et al., 2013). Secara in vitro daun ungu juga diketahui mempunyai aktivitas anti mikroba terhadap S.aureus dengan Konsentrasi Hambat Minimal (KHM) $100 \mathrm{mg} / \mathrm{mL}$ dan diameter hambatan 13,13 mm, karena mengandung flavonoid dan tannin (Erlin dan Marline, 2011).

Daun Semanggi (Marsilea crenata L.) yang mempunyai kandungan alkaloid, steroid dan flavonoid sebagaimana kandungan kimia daun ungu terbukti dapat menurunkan kadar TNF- $\alpha$ pada tikus urolithiasis (Jefry et al., 2013). Daun ungu juga mengandung alkaloid steroid, tannin dan flavonoid (Erlin dan Marline, 2011), diharapkan dapat juga menurunkan kadar TNF- $\alpha$ dan akhirnya dapat menurunkan kadar NO pada infeksi yang diakibatkan oleh S.aureus.

Penggunaan daun ungu sebagai pendamping dalam pengobatan penyakit infeksi ringan yang pada mulanya diawali dengan inflamasi, diharapkan dapat diatasi tanpa memerlukan antibiotika, sehingga ketergantungan terhadap antibiotika yang menimbulkan masalah resistensi dapat dibatasi. Penelitian ini bertujuan untuk membuktikan efektivitas pemberian ekstrak etanol daun ungu dalam menurunkan kadar TNF- $\alpha$ dan NO pada mencit Swiss yang diinfeksi S. aureus serta menganalisis hubungan antara kadar TNF- $\alpha$ dan NO.

\section{METODE PENELITIAN}

Penelitian ini adalah penelitian eksperimental laboratorium dengan the post test only control group design.

\section{Alat dan Bahan}

Hewan coba menggunakan mencit galur Swiss jenis kelamin jantan, umur 4-6 minggu, dengan rerata berat badan $25 \mathrm{~g}$, diperoleh dari Laboratorium Penelitian dan Pengujian Terpadu (LPPT) Universitas Gadjah Mada Yogyakarta. Penggunaan hewan coba telah mendapatkan Sertifikat Ethical Clearance nomor 652/EC/FK/2014 dari Komisi Etik Penelitian Kesehatan (KEPK) Fakultas Kedokteran Universitas Diponegoro Semarang. Hewan coba mencit Swiss sebanyak 30 ekor diadaptasi selama satu minggu, kemudian dibagi menjadi 5 kelompok perlakuan secara random yaitu kontrol negatif (K-), kontrol positif $(\mathrm{K}+), \mathrm{P} 1, \mathrm{P} 2$ dan $\mathrm{P} 3$, masing-masing kelompok terdiri dari 6 ekor. 
Herba yang diuji adalah daun ungu yang diperoleh dari daerah Bandungan, Ambarawa dan telah dilakukan determinasi di Laboratorium Ekologi dan Biosistematik, Fakultas Sains dan Matematika, Jurusan Biologi Universitas Diponegoro. Pembuatan ekstrak etanol daun ungu dilakukan di Laboratorium Kimia Organik Fakultas Sains dan Matematika Jurusan Kimia Universitas Diponegoro Semarang.

Bakteri uji S.aureus ATCC 25923 diperoleh dari Laboratorium Mikrobiologi, Fakultas Kedokteran Universitas Diponegoro.

Alat dan reagen yang digunakan antara lain kandang hewan coba, timbangan digital, sonde lambung, spuit injeksi steril, tabung reaksi steril, media mikrobiologi, seperangkat alat bedah, bilik hitung Neubauer, mikroskop, LPS,PHA, inkubator $\mathrm{CO}_{2}$, sentrifuge, vortex, shaker, blue tip, yellow tip, mikropipet presisi untuk volume $2 \mu \mathrm{L}-1000 \mu \mathrm{L}$. Mikroplat, mikroplat shaker, plate sealer, Reagen RPMI (Roswell Park Memorial Institute) yang mengandung 2\% FBS (Foetal Bovine Serum), Tripan Blue, ELISA Kit Biolegend Legend Max ${ }^{\mathrm{TM}}$ no. katalog 430907 dan ELISA Reader.

\section{Jalannya Penelitian}

\section{Perlakuan hewan coba}

Kelompok kontrol negatif mencit diberi pakan standar dan minum, kelompok kontrol positif mencit diberi pakan standar dan minum, diinfeksi S.aureus. Kelompok P1, P2, dan P3 mencit masingmasing diberi pakan standar dan minum, diinfeksi S.aureus dan diberi ekstrak etanol daun ungu 75 $\mathrm{mg} / \mathrm{kgBB} / \mathrm{hari}, 150 \mathrm{mg} / \mathrm{kgBB} / \mathrm{hari}$, dan $300 \mathrm{mg} / \mathrm{kgBB} /$ hari. Infeksi S.aureus dilakukan pada hari pertama dan pemberian ekstrak etanol daun ungu selama 7 hari dilakukan secara peroral menggunakan sonde lambung.

\section{Infeksi bakteri $S$. aureus}

Staphylococcus aureus dibiakkan pada media Phenol Red MannitolBroth (PRMB). Dari larutan stok satu ose kultur S.aureus diinokulasi ke dalam media PRMB,selanjutnya diinkubasi pada suhu $37^{\circ} \mathrm{C}$ selama 24 jam di dalam inkubator. Staphylococcus aureus yang tumbuh pada media PRMB dipindahkan ke dalam Blood Agar (BA), diinkubasi 24 jam pada suhu $37^{\circ} \mathrm{C}$. Dari media BA diambil 1-2 koloni secara aseptis, dimasukkan ke dalam tabung yang berisi larutan $\mathrm{NaCl} 0,9 \% 2 \mathrm{~mL}$, diaduk dengan kapas lidi steril, sehingga diperoleh kekeruhan yang sama dengan standar kekeruhan larutan 0,5 Mc Farland. Disuntikkan pada mencit $10^{8}$ cfu sebanyak 0,1 mL intraperitoneal (Mufidah et al., 2013).

\section{Uji bakterimia}

Uji Bakterimia dilakukan 1 hari setelah mencit diinokulasikan S. aureus. Darah diambil melalui mata mencit sebanyak $\pm 50 \mu \mathrm{L}$ dan ditampung dalam tabung eppendorf steril, kemudian ditambah dengan $450 \mu \mathrm{L} \mathrm{NaCl}$ 0,9\%. Darah yang tercampur $\mathrm{NaCl} 0,9 \%$ kemudian ditanam pada media Blood Agar Plate (BAP), diinkubasi pada suhu $37^{\circ} \mathrm{C}$ selama 24 jam.

Koloni yang tumbuh pada media BAP ditanam dalam media Heart Infusion Broth (HIB) dalam tabung reaksi dan diinkubasi pada shaker incubator dengan suhu $37^{\circ} \mathrm{C}, 120 \mathrm{rpm}$, selama $36 \mathrm{jam}$. Setelah dilakukan inkubasi, maka dilakukan penanaman pada media Mannitol Salt Agar (MSA). Diambil sebanyak $2 \mathrm{~mL}$ cairan hasil inkubasi dan dilakukan penanaman pada media MSA dengan cara penuangan. Selanjutnya dilakukan inkubasi pada suhu $37^{\circ} \mathrm{C}$ selama 24 jam. Bakteri $S$. aureus dapat mengubah warna media dari merah menjadi kuning (James et al., 2014).

\section{Pembuatan kultur makrofag dari cairan peritoneal}

Pada hari ke 9, mencit dieutanasi dan dibedah, kemudian ditambahkan heparin pada cairan peritoneum. Cairan peritoneum diambil dengan menggunakan spuit injeksi $1 \mathrm{~mL}$, dicuci dengan RPMI (Roswell Park Memorial Institute) yang mengandung 2\% FBS (Foetal Bovine Serum). Setelah dilakukan resuspensi dengan medium komplit, jumlah sel yang didapat dihitung menggunakan bilik hitung Neubauer yang diwarnai dengan Tripan Blue, sehingga didapatkan suspensisel makrofag dengan kepadatan $1 \times 10^{6} / \mathrm{mL}$ untuk pemeriksaan TNF- $\alpha$ maupun NO (Karolina, 2014)

\section{Pengukuran kadar TNF- $\alpha$ dan NO}

Suspensi makrofag dengan kepadatan $1 \times 10^{6} / \mathrm{mL}$ dikultur masing-masing pada microplate 96 sumuran sebanyak $200 \mu \mathrm{L} /$ sumuran untuk pemeriksaan TNF- $\alpha$ dan NO. Untuk pemeriksaan TNF- $\alpha$, 
supernatan kultur makrofag peritoneal ditambahkan $10 \mu \mathrm{L}$ LPS dengan konsentrasi $5 \mu \mathrm{g} / \mathrm{mL}$ pada tiap sumuran. Untuk pemeriksaan NO, supernatan kultur makrofag peritoneal distimulasi dengan $10 \mu \mathrm{L}$ PHA dengan konsentrasi $5 \mu \mathrm{g} / \mathrm{mL}$ pada tiap sumuran, diinkubasi selama 72 jam dalam inkubator $\mathrm{CO}^{2} 5 \%$ pada suhu $37^{\circ} \mathrm{C}$. Supernatan kultur makrofag peritoneal diambil dan dipindahkan ke microplate 96 sumuran lainnya, kemudian disimpan dalam almari es suhu $-80^{\circ} \mathrm{C}$ untuk kapasitas produksi $\mathrm{TNF} \alpha$ dan $\mathrm{NO}$ (Karolina, 2014).

Kadar TNF $\alpha$ diukur dengan menggunakan ELISA Kit Biolegend Legend Max ${ }^{\mathrm{TM}}$ no. Katalog 430907. Tahap akhir dibaca absorbansinya pada panjang gelombang $450 \mathrm{~nm}$ dengan ELISA Plate Reader. Penetapan kadar NO dengan menggunakan metoda Griess dan dibaca absorbansinya pada panjang gelombang $550 \mathrm{~nm}$ dengan ELISA Plate Reader.

\section{Analisis Data}

Data penelitian berupa kadar TNF- $\alpha$ dan NO dari supernatan kultur sel makrofag peritoneal yang dianalisis deskriptif dengan menghitung nilai rerata, selanjutnya disajikan dengan grafik, sedangkan analisis statistik disajikan dengan table. Untuk mengetahui normalitas data dilakukan uji normalitas menggunakan Saphiro Wilk. Uji beda kadar TNF- $\alpha$ menggunakan one way ANOVA, dilanjutkan uji Post Hoc LSD. Kadar NO pada kelima kelompok perlakuan sebaran datanya tidak normal, sehingga digunakan uji Kruskal Wallis untuk melihat adanya perbedaan kadar TNF- $\alpha$ pada kelima kelompok perlakuan.

Analisis data untuk menunjukkan hubungan antara kadar TNF- $\alpha$ dan NO, digunakan uji korelasi Spearmen, karena sebaran datanya tidak normal. Nilai signifikansi pada penelitian ini menggunakan variabel yang dianalisis pada nilai $\mathrm{p}<0,05$.

\section{HASIL DAN PEMBAHASAN}

Setelah mencit diinfeksi dengan $S$. aureus, 24 jam kemudian uji konfirmasi keberadaan S.aureus di dalam darah mencit menunjukkan hasil sesuai yang diharapkan yaitu 24 ekor mencit dari kelompok $\mathrm{K}(+)$ dan P menunjukkan hasil positif terinfeksi S. aureus.

\section{Kadar TNF- $\alpha$.}

Kadar TNF- $\alpha$ diperoleh dari cairan supernatan kultur makrofag peritoneal dengan menggunakan metode ELISA (Gambar I).

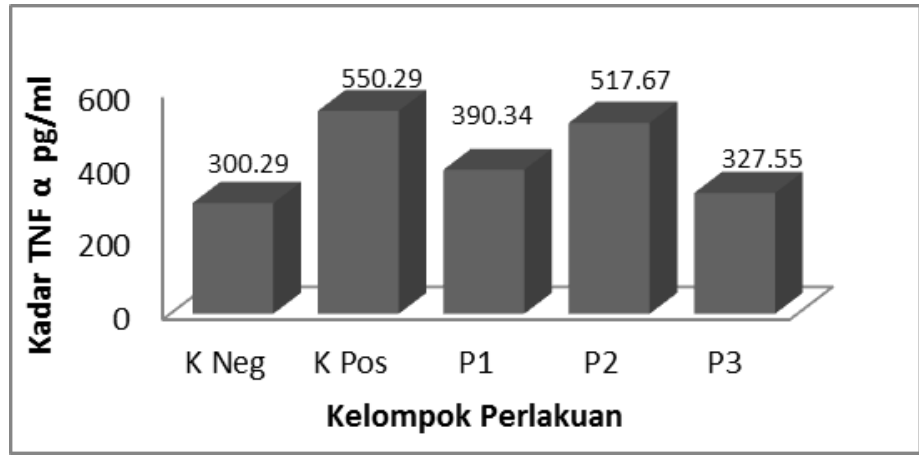

\section{Gambar I. Rerata kadar TNF- $\alpha$ dari cairan supernatan kultur makrofag peritoneal yang distimulasi LPS}

Hasil uji One Way ANOVA menunjukkan terdapat perbedaan bermakna antara ke-enam kelompok perlakuan $(p=0,001)$, sehingga dilakukan uji Post Hoc LSD untuk mengetahui kelompok yang memiliki perbedaan bermakna (Tabel I). 


\begin{tabular}{cccccc}
\hline Perlakuan & Knegatif & Kpositif & $\begin{array}{c}\text { P1 } \\
(\boldsymbol{p} \text { values })\end{array}$ & P2 & P3 \\
\hline Knegatif & & 0,145 & $0.001^{*}$ & 0,652 \\
Kpositif & $0.000^{*}$ & $0,000^{*}$ & $0,013^{*}$ & 0,590 & $0.001^{*}$ \\
P1 & 0.145 & & & $0.043^{*}$ & 0,304 \\
P2 & $0.001^{*}$ & & & $0,004^{*}$ \\
P3 & 0.652 & & & \\
\hline
\end{tabular}

*kelompok yang berbeda bermakna

Kadar TNF- $\alpha$ pada kelompok P1 dan P3 lebih rendah secara bermakna dibanding K (+), sedangkan P2 tidak bermakna dibanding $\mathrm{K}(+)$.

\section{Kadar NO}

Kadar NO diperoleh dari cairan supernatan kultur makrofag peritoneal mencit Swiss yang distimulasi PHA dan diukur dengan ELISA microplate reader pada panjang gelombang $550 \mathrm{~nm}$ (Gambar II).

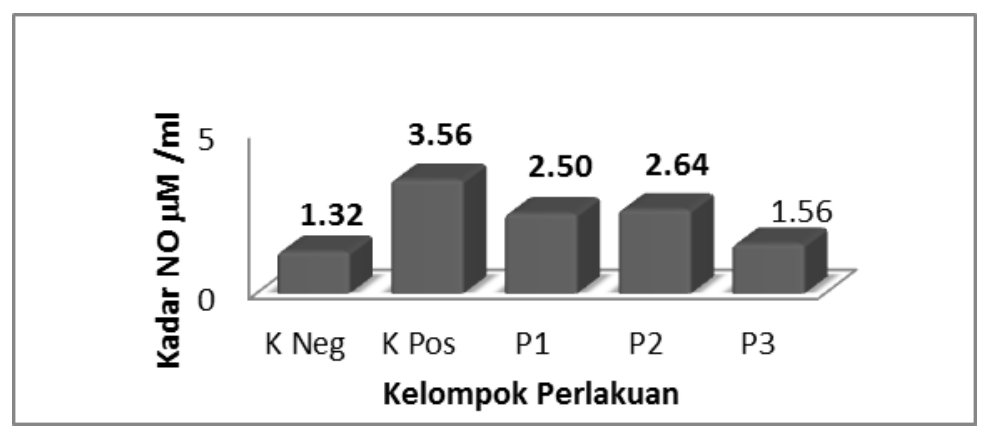

Gambar II. Rerata kadar NO dari cairan supernatan kultur makrofag peritoneal yang distimulasi PHA

Hasil uji statistik dengan Kruskal Wallis test menunjukkan tidak ada perbedaan bermakna antara kelompok perlakuan, meskipun grafik rerata kadar NO memperlihatkan ada penurunan yang mendekati $\mathrm{K}(-)$ pada kelompok perlakuan P3.

\section{Hubungan antara Kadar TNF- $\alpha$ dengan kadar NO}

Uji korelasi Spearman digunakan untuk menganalisa hubungan kadar TNF- $\alpha$ dengan NO (Tabel II). Uji ini dipilih karena data tidak terdistribusi normal. Hasil uji korelasi kadar TNF- $\alpha$ dengan NO pada kelima kelompok perlakuan menunjukkan terdapat korelasi negatif (-) yaitu antara Kneg TNF- $\alpha$ dengan Kneg NO dan P2 TNF- $\alpha$ dengan P2 NO, korelasi positif $(+)$ yang lemah sampai sedang $\left(r_{s}=0,143-\right.$ $0,657)$.

Tabel II. Hasil uji Korelasi Spearman Kadar TNF- $\alpha$ dan NO

\begin{tabular}{cccccc}
\hline $\begin{array}{c}\text { Level of } \\
\text { TNF } \boldsymbol{\alpha}\end{array}$ & Kneg & Kpos & $\begin{array}{c}\text { Level of NO } \\
\text { P1 }\end{array}$ & P2 & P3 \\
\hline K neg & $\mathrm{r}_{\mathrm{s}}=-0,551$ & & & & \\
K pos & & $\mathrm{r}_{\mathrm{s}}=0,143$ & & & \\
P1 & & & $\mathrm{r}_{\mathrm{s}}=0,429$ & & \\
P2 & & & & $\mathrm{r}_{\mathrm{s}}=-0,371$ & \\
P3 & & & & & $\mathrm{r}_{\mathrm{s}}=0,657$ \\
\hline
\end{tabular}

\section{Diskusi}

Hasil penelitian menunjukkan ada peningkatan kadar TNF- $\alpha$ dan NO setelah dinfeksi S.aureus. Penelitian ini juga sejalan dengan penelitian yang dilakukan Kapetanovic et al. (2011), setelah mencit diinfeksi $S$. aureus, 24 jam kemudian terjadi peningkatan produksi TNF- $\alpha$ dalam makrofag peritoneal dibandingkan mencit yang tidak diinfeksi $S$. aureus. 
Bakteri S. aureus merupakan bakteri superantigen (Fraser dan Proft, 2008) yang dapat menstimulasi sel T secara besar-besaran dibandingkan antigen lain. Penelitian Mufidah et al. (2013), melaporkan bahwa interaksi antara superantigen dengan sel dapat menginduksi produksi sitokin dan kemokin dalam sel mencit yang terinfeksi. Sitokin TNF- $\alpha$ dan IL-1 mempunyai aktivitas imunostimulan dan bekerja sinergis dengan IFN- $\gamma$ untuk meningkatkan reaksi imun dan inflamasi. Sitokin-sitokin tersebut dapat bersifat patogen dan menginduksi shock toxic (Krakauer, 2011).

Hasil pengamatan uji menunjukkan bahwa kadar TNF $\alpha$ kelompok perlakuan P1 dan P3 yang diinfeksi S.aureus lebih rendah dibanding kelompok kontrol positif. Penelitian daun Sirsak (Annona muricata L.) dengan zat aktif utama flavonoid juga terbukti dapat menurunkan TNF- $\alpha$ pada mencit Swiss yang diinfeksi Plasmodium berghei ANKA (Karolina, 2014). Ekstrak etanol daun ungu diduga mengandung senyawa aktif yang berfungsi sebagai mediator anti inflamasi sebagai respon adanya superantigen yang mengakibatkan peningkatan sitokin proinflamasi pada mencit yang diinfeksi $S$. aureus. Sejalan dengan penelitian sebelumnya, daun ungu yang mempunyai kandungan senyawa aktif tannin dan flavonoid (Erlin dan Marline, 2011, Sumarny et al. 2013), dapat menurunkan kadar TNF- $\alpha$ pada kelompok perlakuan P1 dan P3. Kelompok P3 dengan dosis $300 \mathrm{mg} / \mathrm{kgBB} / \mathrm{hari}$ bahkan dapat menurunkan kadar TNF- $\alpha$ sampai mendekati kadar kelompok K (-) atau tidak berbeda bermakna dengan kelompok K (-).

Kelompok perlakuan P2 mengalami kenaikan kadar TNF- $\alpha$ lebih tinggi dibandingkan kelompok perlakuan P1. Kenaikan kadar TNF- $\alpha$ tersebut diduga karena pada kelompok perlakuan P2 mengalami inflamasi yang berlebihan karena infeksi S.aureus. Peningkatan inflamasi dalam tubuh mencit tersebut mengakibatkan peningkatan aktivitas makrofag yang berlebihan untuk memproduksi dan mensekresi sitokin proinflamasi TNF- $\alpha$ sebagai indikator terjadinya inflamasi (Fraser dan Proft, 2008). Produksi TNF- $\alpha$ yang berlebihan tidak mampu dihambat oleh ekstrak etanol daun ungu dengan dosis 150 $\mathrm{mg} / \mathrm{kgBB}$.

Kandungan flavonoid utama yang berasal dari ekstrak etanol daun ungu diduga berperan sebagai anti inflamasi (Nieman et al., 2007, Fassihi dan Sabet, 2008), karena infeksi S. aureus. Komponen bioaktif fenol utama pada flavonoid adalah quercetin (Fassihi dan Sabet, 2008). Mekanisme ekstrak etanol daun ungu sebagai anti inflamasi dapat mengakibatkan penurunan kadar TNF- $\alpha$ melalui penghambatan terhadap Nuclear Factor kappa B (NF-kB). Faktor ini menjadi aktif karena adanya stimulus dari agen Reactive Oxygen Synthase (ROS) yang menyebabkan disfungsi endotel, patogen ekposure, kerusakan DNA dan stress fisik. NF-kB berfungsi mengontrol ekspresi gen sitokin dan kemokin proinflamasi TNF- $\alpha$, IL-1 $\beta$ dan IL-6 (Nieman et al., 2007, Fassihi dan Sabet, 2008). Penurunan aktivasi NF-kB dipengaruhi oleh efek inhibisi monosit terhadap enzim protein tyrosin kinase (PTK) p56 yang mengakibatkan PTK tidak aktif (Fassihi dan Sabet , 2008). Protein tyrosin kinase yang tidak teraktivasi menyebabkan faktor transkripsi NF-kB tetap berikatan dengan inhibitor NF-kB, sehingga tidak dapat memicu transkripsi dan translasi dari sitokin proinflamasi TNF- $\alpha$ yang disekresi oleh makrofag. Akibatnya, dapat menurunkan kadar TNF- $\alpha$ (Fassihi dan Sabet, 2008).

Kadar NO dapat diturunkan pada mencit yang diinfeksi S.aureus dan diberi ekstrak etanol daun ungu $-300 \mathrm{mg} / \mathrm{kgBB}$ selama 7 hari hingga mendekati kadar NO pada kelompok K(-). Data hasil uji menunjukkan bahwa kadar NO kelompok perlakuan P1 dan P3 yang diinfeksi $S$. aureus dan diberi ekstrak etanol Daun ungu lebih rendah dibanding kelompok kontrol positif. Penelitian ini selaras dengan penelitian terdahulu dengan buah Mengkudu (Morinda citrifolia) yang mempunyai kandungan antioksidan kuat seperti beta karoten, alkaloid, terpenoid dan flavonoid, yang juga terbukti dapat menurunkan kadar NO pada tikus terpapar asap rokok (Anggraini, 2012).

Kelompok perlakuan P2 mengalami sedikit kenaikan kadar NO yang lebih tinggi dibandingkan kelompok perlakuan P1. Kenaikan kadar NO tersebut diduga pada kelompok perlakuan P2 terjadi infeksi dan inflamasi yang berlebihan, karena bakteri $S$. aureus. Infeksi yang berlebihan menyebabkan kenaikan jumlah NO yang lebih banyak dibanding kelompok P1, karena infeksi kuman dan tidak mampu dihambat oleh ekstrak etanol daun ungu dengan dosis $150 \mathrm{mg} / \mathrm{kgBB}$.

Jumlah NO yang berlebihan karena infeksi kuman akan diubah menjadi peroksinitrit (ONOO-) yang merupakan radikal bebas, sehingga sel mengalami stress oksidatif (Oca et al., 2005). Flavonoid juga berfungsi menetralisir efek toksik radikal bebas. Mekanisme flavonoid untuk netralisasi radikal bebas

Pharmaciana Vol. 6, No. 2, November 2016, Hal. 191-200 
dengan cara mendonorkan ion hydrogen sehingga ion yang mengalami radikal bebas $\left(\mathrm{OH}^{-}\right)$diregenerasi menjadi $\mathrm{H}_{2} \mathrm{O}$ yang stabil (Astuti, 2008). Keadaan ion yang telah stabil menyebabkan menurunnya stress oksidatif di dalam jaringan, yang akhirnya akan menurunkan kadar NO (Sumardika dan Jawi, 2012).

Penelitian yang dilakukan Komine et al., (2004) pada albumin kelenjar mammae sapi yang diinfeksi enterotoksin staphylococcus menunjukkan bahwa kenaikan sitokin proinflamasi TNF- $\alpha$ juga memicu kenaikan produksi NO. Studi yang dilakukan Fonseca pada mencit Leismaniasis menunjukkan bahwa pemberian anti TNF- $\alpha$ dapat meningkatkan jumlah parasit dan ukuran lesi. Peningkatan ukuran lesi berhubungan dengan aktivitas iNOS makrofag peritoneal mencit. Studi tersebut menunjukkan bahwa TNF- $\alpha$ merupakan mediator yang dapat menginduksi produksi NO di makrofag (Fonseca et al., 2003).

Studi yang lain menunjukkan bahwa induksi NO tidak hanya diperantarai oleh TNF- $\alpha$ saja, tetapi juga dipicu oleh sitokin proinflamasi lain. Penelitian yang dilakukan Chan et al. (2001)., kombinasi antara IFN- $\gamma$ dan dinding sel Mycobacterium berupa lipoglikan dapat mengiduksi ekspresi iNOS dan NO pada makrofag. (Chen et al., 2003) melaporkan bahwa peningkatan IFN- $\gamma$ akan memicu peningkatan inducible NO synthase, demikian juga peningkatan IL-1 $\beta$ di pembuluh darah sel otot polos tikus juga akan memicu peningkatan transkripsi gen yang menyebabkan peningkatan inducible Nitric Oxide Synthase (iNOS), tetapi aktivitasnya dilemahkan oleh heme oxygenase-1 (HO-1) (Yang et al., 2004).

\section{KESIMPULAN}

Pemberian ekstrak etanol daun ungu dosis $300 \mathrm{mg} / \mathrm{kgBB}$ dapat menurunkan kadar TNF- $\alpha$ dan NO secara bermakna pada mencit Swiss yang diinfeksi S. aureus. Ada korelasi positif antara penurunan kadar TNF- $\alpha$ dan NO pada mencit yang diinfeksi $S$. aureus dan diberi ekstrak daun Ungu dengan hasil bervariasi pada setiap kelompok perlakuan. Ekstrak etanol daunungu dosis 300mg/kgBB/hari selama 7 hari, yang merupakan dosis efektif untuk menurunkan kadar TNF- $\alpha$ dan NO pada mencit Swiss yang diinfeksi S. aureus.

\section{UCAPAN TERIMAKASIH}

Penulis mengucapkan terima kasih kepada Akademi Analis Farmasi 17 Agustus 1945 Semarang sebagai penyumbang dana untuk reagen, teknisi di bagian Mikrobiologi Fakultas Kedokteran UNDIP Semarang, teknisi LPPT UGM dan Laboratorium MIPA Kimia UNDIP. Ririn Lispita Wulandari dan Annaas Budi Setyawan yang telah memberikan saran dan masukan, sehingga terselesaikannya penelitian ini.

\section{DAFTAR PUSTAKA}

Abbas AK., Lichtman AH., Shiv Pillay., 2012, Cellular and Molecular Immunology $7^{\text {th }}$ ed. WB Saunders Co. Philadelphia.,243-297, 345-355

Anggraini H., 2012, Pengaruh Pemberian Jus Mengkudu (Morinda citrifolia L.) terhadap Nitric Oxide (NO) dan Reactive Oxygen Intermediate (ROI) Tikus yang Terpapar Asap Rokok, Magister Ilmu Biomedik Universitas Diponegoro Semarang, 60-68

Astuti S., 2008, Isoflavon kedelai dan potensinya sebagai penangkap radikal bebas., Jurnal Teknologi Hasil Pertanian Universitas Lampung, 126-136

Baratawidjaja KG., Rengganis I., 2009, Imunologi Dasar Edisi 8., Fakultas Kedokteran Universitas Indonesia Jakarta, 217-254, 399-411

Chan ED., Morris KR., Belisle JT., Hill P., Remigio LK., Brennan PJ., Riches DWH., 2001, Induction of inducible nitric oxide synthase-no by lipoarabinomannan of Mycobacterium tuberculosis is mediated by MEK1-ERK, MKK7-JNK, AND NF-KB signaling pathways. Infect Immun, 20012010.

Chen CW., Chang YH., Tsi CJ, Lin WW., 2003, Inhibition of IFN-gamma-mediated inducible nitric oxide synthase induction by the peroxisome proliferator-activated receptor gamma agonist, 15deoxy-delta 12, 14-prostaglandin $\mathrm{J} 2$, involves inhibition of the upstream janus kinase/STAT1 signaling pathway. J Immunol., 979-988.

Erlin S dan Marline N., 2011, Aktivitas antibakteri dan analisis kandungan kimia daun ungu (Gratophyllum pictum(L.)Griff), Prosiding Seminar Nasional Biologi "Meningkatkan peran Biologi dalam mewujudkan National Achievement with Global Reach", Universitas Sumatera Utara, 245-250. 
Fassihi A., Sabet R., 2008, Qsar study of $\mathrm{p} 56^{\mathrm{lck}}$ protein tyrosine kinase inhibitory activity of flavonoids derivatives using MLR and GA-PLS. Int.J.Mol.Sci,1876-1892.

Fonseca SG., Ramano PRT., Figuiredo F., Marais RH., et al., 2003, TNF $\alpha$ mediated the induction of nitric oxide synthase in macrophage but not in neutrophils in experimental cutaneous leishmaniasis. Eur J Immunol, 2297-2306.

Fraser JD., Proft T., 2008, The bacterial superantigen and superantigen-like proteins. Immunol Rev,226243.

Gillian MW., Simon JF., Charles JH., Christop T., 2001, A cell wall component from pathogenic gram positive bacteria (Peptidoglycan) synergises with endotoxin to cause the release of tumor necrosis factor $\alpha$, nitric oxide production, shock and multiple organ injury/disfunction in the rat. Shock,135-142.

Giuseppe C., Eleonora D., John LW., 2006, Nitric oxide and inflammation. Inflamm Allergy Drug Targets, 115.

James G. Capuccino., Natalie Sherman., 2014, Manual Laboratorium Mikrobiologi. Alih bahasa: Nur Miftahurrahmah, Jakarta: EGC., 103-106, 146-149.

Jefry H., Pratiwi T, Djoko W., 2013, Efek perasan daun dan tangkai semanggi air (Marsilea crenata) terhadap penurunan kadar tumor necrosis factor alpha $(T N F-\alpha)$ dan interleukin $1 \beta$ (IL-1 $\beta)$ pada tikus putih (Rattus norvergicus) urolithiasis. Program Kedokteran Hewan Universitas Brawijaya, Malang., 1-11.

Kapetanovic R., Pariato M., Fitting C Quesnlaux., Cavallon JM., Adib-Conquy., 2011, Mechanism of TNF- $\alpha$ induction by heat-killed Staphylococcus aureus differ upon the origin of mononuclear phagocytes. Am J Physiol Cell Physiol., 850-859.

Karolina ME., 2014, Efektivitas ekstrak daun sirsak (Annona muricata) dalam menurunkan TNF $\alpha$ dan meningkatkan kadar NO (uji coba pada mencit swiss yang diinokulasi Plasmodium berghei ANKA), Magister Ilmu Biomedik Universitas Diponegoro Semarang., 44-51, 60-66

Komine K., Kuroishi T., Komine Y., Watanabe K., Kobayashi J., Yamaguchi T., Kamata S., Kumagai K., 2004, Induction of nitric oxide production mediated by tumor necrosis factor alpha on Staphylococcal enterotoxin C-stimulated bovine Mammary Gland Cells. Clin Diagn. Lab. Immunol., 203-210.

Krakauer T., 2011, Comparative potency of green tea and red wine polyphenols in attenuating staphylococcal superantigen-induced imun responses. American Journal Biomedical Sciences, 157-166.

Lestari ES., Severin JA., Verbrugh HA., 2012, Antimicrobial resistance among pathogenic bacteria in Southeast Asia. Southeast Asian J Trop Med Public Health.,385-422

Mufidah M, Rifa'i M, dan Rahayu S, 2013, Aktivitas imunomodulator ekstrak buah mengkudu pada mencit yang diinfeksi Staphylococcus aureus, Jurnal Veteriner.,501-510.

Nickerson EK., Hongsuwan M., Limmathurotsakul D., Wuthiekanun V., Shah KR., et al., 2009, Staphylococcus aureus Bacteraemia in a tropical setting: patient outcome and impact of antibiotic resistance. Plos One, 4308.

Nieman DC, Henson DA, David M, Murphy EA, Jenkins DP, Gross SJ, Carmichael MD, Quindry JC, Dumke CL, Utter AC, McAnulty SR, McAnulty LS, Triplett NT, Mayer EP, 2007, Quercetin influence on exercise-induced changes in plasma cytokins and leukocyte cytokine mRNA. Jappphysiol, 1728-1735.

Oca MM., Torres SH., Sanctis D., Mata A., Hernandez N., Talamo C., 2005, Skeletal muscle inflammation and nitric oxide in patients with COPD. Eur.Respir.J., 390-397.

Okeke IN., Klugman KP., Bhutta ZA., Duse AG., Jenkins P., O’brien TF., Pablas-Mendez A., 2005, Antimicrobial resistance in developing countries part II : strategy of countainment. Lancet., 568580.

Ozaki Y., Sekita S., Soedigdo S., Harada M., 1989, Anti inflammatory effect of Gratophyllum pictum (L.) Griff.,Chem Pharm Bull (Tokyo), 2799-2802.

Sharma JN., Al-Omran A., Parvathy SS., 2007, Role of nitric oxide in inflammatory disease, Inflammopharmacology., 252-259 .

Pharmaciana Vol. 6, No. 2, November 2016, Hal. 191-200 
Sumardika IW., Jawi I.M., 2012, Ekstrak air daun ubi jalar ungu memperbaiki profil lipid dan meningkatkan kadar SOD darah tikus yang diberi makanan tinggi kolesterol. Medicina, 67-71.

Sumarny R., Yuliandini., Rohani M., 2013, Efek anti inflamasi dan anti diare ekstrak etanol herba Meniran (Phylanthus niruri L.) dan daun ungu (Gratophyllum pictum (L.) Griff. Prosiding Seminar Nasional Perkembangan Terkini Sains Farmasi dan Klinik III., 207-211.

Sumastuti R., 2000, Efek infus daun ungu (Gratophyllum pictum (L.)Griff) pada usus kelinci terisolasi dalam kaitannya dengan obat wasir. Warta Tumbuhan Obat Indonesia,1-3.

Wang JE., Jergensen PF., Almiof M., Thiemermann C., Foster SJ., Aasen AO., Solberg R., 2000, Peptidoglycan and Lipoteichoic acid from Staphylococcus aureus Induce Tumor Necrosis Factor Alpha, Interleukin 6 (IL-6) and IL-10 Production in Both Tcells and Monocytes in Human Blood Model. Infect Immun., 3965.

Yang NC., Lu LH., Kao YH., Chau LY., 2004, Heme oxigenase-1 attenuates interleukin-1 beta-induced nitric oxide synthase expression in vascular smoth muscle cells. J Biomed Sci.,799-809. 
